University of Nebraska - Lincoln

DigitalCommons@University of Nebraska - Lincoln

Management Department Faculty Publications

Management Department

8-2008

Learning: The Interface of Quality Management and Strategic Alliances

Mahour Mellat-Parast

University of North Caro-lina-Pembroke, Pembroke, NC

Lester Digman

University of Nebraska - Lincoln, Idigman1@unl.edu

Follow this and additional works at: https://digitalcommons.unl.edu/managementfacpub

Part of the Management Sciences and Quantitative Methods Commons

Mellat-Parast, Mahour and Digman, Lester, "Learning: The Interface of Quality Management and Strategic Alliances" (2008). Management Department Faculty Publications. 27.

https://digitalcommons.unl.edu/managementfacpub/27

This Article is brought to you for free and open access by the Management Department at DigitalCommons@University of Nebraska - Lincoln. It has been accepted for inclusion in Management Department Faculty Publications by an authorized administrator of DigitalCommons@University of Nebraska - Lincoln. 


\title{
Learning: The Interface of Quality Management and Strategic Alliances
}

\author{
Mahour Mellat-Parast \\ Department of Economics, Finance, and Decision Sciences, School of Business Administration, University of North Caro- \\ lina-Pembroke, Pembroke, NC 28372, USA; email mahour.parast@uncp.edu (Corresponding author)
}

\section{Lester A. Digman}

Department of Management, College of Business Administration, University of Nebraska-Lincoln, Lincoln, NE 68588, USA; email $\underline{\text { digman1@unl.edu }}$

\begin{abstract}
In this paper, we investigate the practice of quality management in strategic alliances. By employing a relational view of inter-organizational competitive advantage, the paper addresses the concept of quality management in strategic alliances and networks. We argue that institutional/network relationships influence the practice of quality within a network. In that regard, firms that have adopted quality management practices are more effective in managing and coordinating their interactions with other firms in the network, which results in their enhanced learning capability within the alliance. The proposed framework recognizes the role of trust and cooperative learning as critical factors that affect the success of strategic alliances. It has been argued that firms within an alliance need to achieve the paradox of control and learning. We examine the role of trust as a control mechanism in strategic alliances and address the importance of cooperative learning within alliances. Several hypotheses have been proposed and future research has been outlined.
\end{abstract}

Keywords: quality management, strategic alliances, trust, learning

\section{Introduction}

Quality management (QM) has been widely viewed as a management paradigm that enables firms to gain a competitive advantage (Yeung et al., 2006). Kanji (1990, p. 4) describes QM as "the second industrial revolution." Empirical research shows that QM practices positively affect firm performance (Hendricks and Singhal, 1996; Handfield et al., 1998; Das et al., 2000; Douglas and Judge, 2001; Hendricks and Singhal, 2001a, 2001b; Kaynak, 2003).

A fundamental question in QM is to determine whether firms operating in a network are embracing quality, and if they are, to what extent QM is adopted differently by different members of the network (Sitkin et al., 1994). Furthermore, to the extent that firms operating in networks have adopted QM programs, how are the dual goals of control and learning addressed? We attempt to inves- tigate how QM could be practiced within a network of firms, and to what degree the practice of quality may be different.

The traditional view towards QM has been focused on the practice of quality within a single firm. While scholars raise the question regarding the domain of QM (Sousa and Voss, 2002), there is some evidence on the literature that provides insight on the role of QM in a network of firms. Recent studies show that there are synergies between QM and supply chain management performance (Flynn and Flynn, 2005). Robinson and Malhotra (2005) define quality in a supply chain management, and they argue that understanding QM in a supply chain environment requires a transition from a product to a process-oriented perspective towards quality. A recent study by Lo et al. (2007) states that QM is a prerequisite for effective supply chain management. 
To extend QM and define its practice within a network of firms, we focused on strategic alliances.* Scholars and practitioners are interested to know the critical success factors for such alliances (Gulati, 1998; Gulati et al., 2000; Arino et al., 2001; Inkpen and Ross, 2001; Sampson, 2005; Singh and Mitchell, 2005; White and Lui, 2005). Despite the significant attention given to quality, strategic management remains a key area of extension of the quality concept (Pruett and Thomas, 1996). Our aim is to address the practice of quality within a network so that firms can achieve a higher level of performance.

This paper extends the concept of quality beyond the scope of a firm by providing a network perspective of quality. It contributes to the existing body of knowledge in understanding successful strategic alliances.

\section{Theoretical background}

The purpose of the paper is to investigate the practice of QM in strategic alliances. A learning perspective of strategic alliances has been employed to understand the dynamics and evolution of inter-firm collaborations within a network of firms. We utilize a knowledge-based view of competitive advantage, arguing that inter-firm resources and routines (e.g. knowledge sharing routines) can be sources of competitive advantage (Dyer and Singh, 1998).

Previous studies show that both the top manager and network/institutional factors influence the adoption of new innovation practices such as QM (Young et al., 2001). However, in the context of a single firm, top management is the driving force for quality initiatives (Wilson and Collier, 2000). We argue that the practice of QM within a firm will be different from the practice of QM within an alliance (Westphal et al., 1997; Young et al., 2001). To address the practice of quality in strategic alliances, a process orientation of quality has been employed (Robinson and Malhotra, 2005).

\subsection{Traditional view vs. the network view towards quality}

The traditional view towards quality is different from the network view towards quality. Here we explain the characteristic of both approaches towards quality:

Level of analysis: The fundamental difference between the traditional view and the network view is the level of analysis. The traditional view towards quality looks at a firm as the level of analysis (Sousa and Voss, 2002). However, within a network the overall quality of the network is addressed, referring to the network as the unit of analysis.

Decision making: It is believed that within a firm top management is the major driver of QM who leads the quality initiative (Flynn et al., 1994; Wilson and Collier, 2000; Kaynak, 2003). However, in a network of firms it is the network governance and structure that guides quality systems. From the institutional/network perspective, firms may adapt new practices (such as QM) that do not necessarily increase their performance. Rather, such reinforce- ment comes from the network. In the context of a firm, the decision to purse a specific quality initiative is primarily determined within the scope of the firm. The dynamics will be different as firms move towards the network (Westphal et al., 1997; Young et al., 2001).

Sources of competitive advantage: Strategy literature identifies different theoretical lenses to address the sources of competitive advantage of firms. The resource-based view (RBV) argues that superior firm performance is the result of the ability of firms to accumulate resources and capabilities that are rare, valuable, and difficult to imitate (Rumelt, 1984; Barney, 1991). In this view, RBV focuses on a firm as the unit of analysis.

The relational view of competitive advantage claims that inter-firm linkages may be a source of competitive advantage. This view suggests that a firm's critical resources may span firm boundaries and may be embedded in inter-firm resources and routines (Dyer and Singh, 1998).

The traditional view towards QM has been focused on a firm as a unit of analysis where it employs a RBV perspective towards quality and the role of quality as a source of competitive advantage (Powell, 1995; Escrig Tena et al., 2001). However, as we move across and beyond the scope of a firm, the sources of competitive advantage are embedded in the network. This requires looking at QM from the relational view.

\section{Cooperation and alliances}

Previous studies show that cooperation and networking enhance firm's performance and profitability (Smith et al., 1995; Gulati et al., 2000). According to Gulati (1998) strategic alliances are "voluntary arrangements between firms involving exchange, or co-development of products, technologies, or services" (p. 293). Arino et al. (2001) stated that strategic alliance involves "a formal agreement to pursue a set of private and common goals through the sharing of resources in contexts involving consented markets and uncertainty over outcome" (p. 110). Gulati (1995) referred to strategic alliances as "any independently initiated interfirm link that involves exchange, sharing, or co-development [among partners]" (p. 86). Zollo et al. (2002) defined strategic alliances as "cooperative agreement of any form aimed at the development, manufacture, and/or distribution of new products" (p. 701). According to Smith et al. (1995), while cooperation and coordination within organization and between firms were not new in the management and organizational studies, the emergence of total QM philosophies emphasized more need for cooperation throughout organizations and between firms. For the purpose of this paper, strategic alliances are defined as long-term cooperation between firms aimed at achieving a shared (common) set of goals through cooperative learning between partners.

Different theoretical perspectives have been used for understanding strategic alliances. One perspective is transactions cost analysis, which focuses on the cost of

\footnotetext{
* By strategic alliances we refer to two or more firms cooperating within a network.
} 
conducting and maintaining relationships between organizations (Williamson, 1979; Heide, 1994). Through a comparative analysis of inter-firm collaboration in the auto industry between the US and Japan, Dyer (1996) showed that transaction costs did not necessarily increase with an increase in relation-specific investment. His findings supported an inverse relationship between trust and transaction cost. The findings suggest that Japanese auto firms tended to trust their suppliers and made the investments based on oral premises of the automaker and without a written agreement. Reliance on trust enabled Japanese firms to minimize their transaction cost, and was a highly effective and low-cost mechanism for safeguarding specialized investments.

From a social network perspective, Gulati (1998) argued that there were three main motivations for formation of alliances: transaction cost resulting from small numbers bargaining, strategic behavior that leads firms to enhance their competitive behavior, and learning. According to Gulati (1995), the problem with transaction cost theory was the exclusion of inter-firm trust. To avoid this shortcoming, a learning perspective of strategic alliances has been employed in this paper.

\section{Introducing quality management to strategic alliances}

The ultimate goal of QM is to establish a management system and an organizational culture that ensures customer satisfaction and continuous improvement (Sitkin et al., 1994; Hackman and Wageman, 1995; Kaynak, 2003).

Reed et al. (1996) indicated that there was no consensus on the definition for QM since its definition varied based on the approach taken towards quality. According to Flynn et al. (1994), QM is "an integrated approach to achieving and sustaining high-quality output, focusing on the maintenance and continuous improvement of processes and defect prevention at all levels and in all functions of the organization, in order to meet or exceed customer expectations" (p. 342). Dean and Bowen (1994) conceptualized $\mathrm{QM}$ in terms of principles, practices, and techniques. The principles are customer focus, continuous improvement, and teamwork. Each principle includes a set of practices, like direct customer contact, process analysis, group skills training, and collaboration with suppliers. These practices, then, are implemented through a number of techniques, like quality function deployment, control charts, cause and effect diagrams, team building, six-sigma, and so on. Anderson et al. (1994) perceived QM as a holistic approach to organization-wide quality, operationalized through leadership, internal/external cooperation, effective process management, product design, learning, customer focus and involvement, employee fulfillment, and continuous improvement.

Despite the differences among scholars and practitioners on the definition of QM and its components, most studies refer to the Malcolm Baldrige National Quality Award
(MBNQA) as the reference model for QM. The Baldrige Award consists of seven criteria, including leadership, customer and market focus, measurement, analysis and knowledge management, human resource management, process management, and business results. Within this framework, most studies indicate that leadership is the main drive for achieving business results and customer satisfaction (Wilson and Collier, 2000; Flynn and Saladin, 2001; Evans and Jack, 2003).

In terms of core principles of QM, Sitkin et al. (1994) conceptualized QM as customer satisfaction, continuous improvement, and systems view of organization. This definition of quality is compatible with (Deming, 1986, 1994). Consistent with previous studies on QM, knowledge creation, and learning (Linderman et al., 2004), we utilize the definition proposed by Sitkin et al. (1994). We argue that the learning perspective of QM provides valuable insight to address learning in strategic alliances.

\subsection{Quality management and learning}

It is believed that QM practices that result in knowledge creation enhances organizational performance (Linderman et al., 2004). QM literature characterizes quality in two dimensions: control and learning (Sitkin et al., 1994). Effective implementation of $\mathrm{QM}$ is contingent upon a balance between control and learning, achieving conflicting goals of stability and reliability with those of exploration and innovation. The effectiveness of QM relies on the coexistence of these two incompatible approaches to quality (LeonardBarton, 1992). To the extent that a balance between control and learning has been maintained, a sustainable quality strategy will be achieved.

Several scholars have pointed out to the link between quality and process improvement (Fine, 1986; Fine and Porteus, 1989; Marcellus and Dada, 1991; Li and Rajagopalan, 1998). One of the first studies that related quality and learning was conducted by Fine (1986). He found that over time the organization optimal quality level increases due to the learning effect. In another study Fine and Porteus (1989) argued that decreasing the uncertainty of the process (making the potential improvements more predictable) has a desirable effect on process improvement. Li and Rajagopalan (1998) analytically showed that quality improved over time, while process improvement effort and quality assurance effort decreased over time.

Deming (1982) argues that knowledge and learning are crucial mechanisms for sustaining a competitive advantage, especially during periods of rapid change. Through focus on learning, knowledge creation, and processes innovation, the quality movement was able to address the adaptability of the organization in highly uncertain and changing environments (Sitkin et al., 1994). In fact, in highly uncertain contexts, QM needs to focus on experimentation (learning) rather than on decreasing error rates (control). According to Sitkin et al. (1994) in uncertain environments QM "stresses improvement in learning capability which includes effec- 
tively identifying new skills and resources to pursue, the ability to explore these new areas, and the capacity to learn from that exploration" (p. 546).

Previous studies on QM argue that the goal of QM needs to be balanced depending upon the uncertainty of the situation; in a stable and routine environment the goal is [quality] control while in non-routine situations the goal is learning.

\subsection{Dynamics of quality management in strategic alliances}

According to institutional theory of the firm, the adoption of new administrative innovations (such as QM) is an institutional process subject to competitive and institutional effects (Yeung et al., 2006). Westphal et al. (1997) defined QM as "a managerial innovation that emphasizes an organization's commitment to the customer and to continuous improvement of every process through the use of data-driven, problem-solving approaches on empowerment of employee groups and teams." (p. 367). A social network can influence the form of practices organizations introduce. It has been argued that institutional forces affect both QM adoption and its content. Due to the institutional/network effect, firms restructure their QM practices and develop a new set of practices compatible with the new settings (Browning et al., 1995). This calls for a new QM content and process within strategic alliances (Westphal et al., 1997).

Another relevant issue that bridges QM and strategic alliances together is the role of learning in alliances (Morrison and Mezentseff, 1997). QM emphasizes learning (Hackman and Wageman, 1995; Linderman et al., 2004). As Garvin (1993) pointed out, continuous improvement would not happen until there was a learning environment. It is believed that continuous improvement and knowledge creation are vital activities of QM (Dean and Bowen, 1994; Kolesar, 1994). A recent study by Linderman et al. (2004) demonstrates the link between QM and knowledge creation, where QM practices create knowledge and enhance organizational learning, which leads to higher performance.

Regarding the overall quality of strategic alliances, Arino et al. (2001) argue that in achieving the objectives of strategic alliances, reliance on trust is not sufficient since trust is a complex issue and management should focus on a broader concept - the quality of the alliance and the critical success factors of enhancing the overall quality of the alliance. By defining relational quality as "the extent to which the partners feel comfortable and are willing to rely on trust in dealing with one another" (p. 111), they clarify that relational quality encompasses a broader concept than trust, such as degree of compatibility of corporate culture and decision-making style, and a convergence of worldviews. However, the development and evolution of relational quality as well as its relationship to the alliance performance has not been addressed in previous studies. We address this issue from the QM perspective.

\subsection{Learning perspective of quality management in alliances}

In the context of a network of firms, learning has been defined as the process of acquisition and exploitation of new knowledge, skills, and competencies by the organization (Argyris and Schön, 1978; Cohen and Levinthal, 1990; Muthusamy and White, 2005). While the level of learning within an alliance depends upon the absorptive capacity of partners, the success of the collective learning effort is determined by the cooperative learning among partners $(\mathrm{Mu}-$ thusamy and White, 2005).

Love et al. (2002) provided a framework for strategic partnership in reference to QM. They argued that successful strategic alliance requires systems thinking, a learning culture, knowledge and communication, changing mental models, joint learning structure/process, and development of learning relationships. Through a case study (interview) with managers in the construction industry, they found that the strategic alliance resulted in improved problemsolving skills, project management performance, knowledge and competence of workers, inter-organizational relationships, and stakeholders' satisfaction. In order to benefit from knowledge and expertise of the partners in the alliances, a systematic approach to alliance learning needs to be established. Development of such a learning environment requires leadership commitment in the learning process (Inkpen, 2005).

Furthermore, there is a link between learning as one of the objectives of alliances and QM. In fact, the ability of QM-driven organizations to evolve to a learning organization prepares them for successful strategic alliances. Garvin (1993) pointed out organizations that were committed to QM would be uniquely prepared for learning. According to Crossan and Inkpen (1995), the ability to learn is critical to the success of strategic alliances. Since QM emphasizes learning (Garvin, 1993), successful implementation of QM would enhance learning in alliances. However, from the network/institutional theory perspective, firms need to adopt their QM practices to the environmental forces. The network/institutional theory recognizes the role of normative pressures from the network on the firms within a network as the major source of change and innovation of management practices in a firm. Such innovations and change within a firm are not because of productivity and efficiency improvement per se; rather, firms adapt new management practices because of the pressure from the network (Meyer and Rowan, 1977; DiMaggio and Powell, 1983; Judge and Zeithaml, 1992).

Based upon the above and for the purpose of this paper, QM within strategic alliances has been defined as

the coordination and integration of all business activities (e.g. processes and procedures) involving all partners (firms) in the alliance through continuous improvement of processes to enhance performance and achieve customer satisfaction-a key part of which is continuous learning. 
The above definition reflects a process orientation towards understanding quality in strategic alliances-an approach that has been recommended by Robinson and Malhotra (2005). The process approach is critical for understanding quality with respect to the emphasis on learning in alliances. Such a definition for quality resolves the shortcomings of previous approaches for relating quality to strategic alliances in a network of firms, to the extent that it focuses on the processes (rather than the product) within the alliance.

With reference to the above definition and to the extent that the objective of strategic alliances is learning, we now present the central proposition of this paper:

P: To the extent that the objective of strategic alliances is learning, firms which have adopted quality management practices outperform firms which do not have quality management practices. In other words, firms that have been adopted quality management exhibit higher level of learning capability (absorptive capacity) than firms which do not have adopted quality management practices.

\section{Development of concepts and their relationships}

In this section, a model for QM in strategic alliances is introduced and defined. Each element of the model is grounded with the relevant literature and evidence is provided to support its inclusion. Figure 1 shows the conceptual framework and the relationship between the variables.

Trust: Ring and Van de Ven (1994) defined trust as "an individual's confidence in the good will of the others in a given group and belief the others will make efforts consistent with the group's goal" (p. 110). Wicks (2001) argued that trust was a critical facilitator of cooperation and a vital ingredient of QM. Trust is regarded as a central prerequisite for starting any inter-organizational project and must be present from the beginning (Arnulf et al., 2005). Empir- ical evidence showed that employee trust in the manager was found to be significantly related to sales, profit, and employee turnover (Davis et al., 2000). Trust is generally believed to be important in the success of inter-firm relationship (Jeffries and Reed, 2000; Williams, 2007).

Strategic intent (direction): Having a common strategic direction (intent) helps firms to have a better understanding of their mutual goals and expectations (Ellram, 1990). According to Lo and Yeung (2004), having a common strategic direction is a requirement for effective supplier integration in strategic alliances. Strategic intent has been regarded as an important characteristic in strategic alliances (Zollo et al., 2002). Experienced partners should recognize that changes in their strategic objectives pose a greater threat to relational quality than do most exogenous events (Arino et al., 2001).

Cultural compatibility: Smith et al. (1995) argued that similarities in the partners' values contributed to the level of cooperation. It is evident that cultural closeness among firms facilitates communication between individuals, which is based upon achieving mutual understanding and trust. Zollo et al. (2002) regarded organizational culture as one of the firm-level variables in studying alliance performance.

Alliance governance (leadership): Smith et al. (1995) found that leaders could play an important role in building trust within the alliance. Leaders can play an essential role in facilitating the learning process within the alliance (Inkpen, 2005), and can enhance the effectiveness of supply chain partnership (Wong, 2001). In the Baldrige Award criteria, leadership is the most important factor and has a direct impact on the effective implementation of quality systems (Wilson and Collier, 2000).

Process improvement: Both practitioners and scholars recognize continuous improvement as one of the major principles of QM (Dean and Bowen, 1994; Hackman and Wageman, 1995). According to Lo and Yeung (2004), continuous improvement plays an important role in strategic alliances.

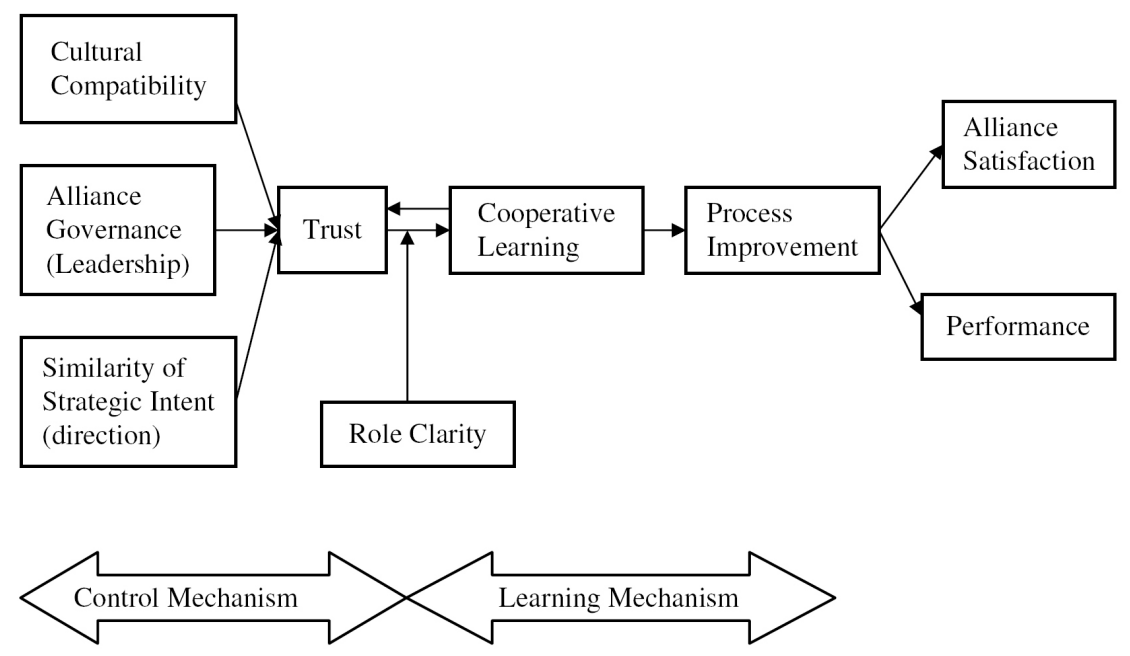

Figure 1. Generic model for quality management in strategic alliances. 
Cooperative learning: Cooperative learning refers to the mechanisms through which partners can share knowledge, information, and resources. Organizations develop cooperative relationships through creating a learning environment so that they can facilitate mutual learning. Cooperative learning emphasizes the role of cooperation in alliances, rather than competition (Morrison and Mezentseff, 1997).

Role clarity: Role clarity refers to the distribution of tasks, roles, and responsibilities between companies based on each company's core competency (Prahalad and Hamel, 1989)-activities that give them competitive advantage (Porter, 1985; Stabell and Fjeldstad, 1998; Christopher, 1998; Arnulf et al., 2005).

\subsection{The conceptual model for quality management within strategic alliances}

According to Arnulf et al. (2005), the success of inter-organizational projects is subject to two types of dynamics: (1) a mutual absorptive learning capacity and (2) the development of institutional trust among the partners. A certain minimum level of inter-firm trust is indispensable for any strategic alliance to be formed and to function (Das and Teng, 1998).

It is believed that the formation of trust within a strategic alliance is related to the values, attitude, and moods and feelings of parties (Jones and George, 1998). Browning et al. (1995) pointed out that productive communication among partners has been weakened due to the cultural differences. Familiarity and shared experience have been considered as sources of trust, where differences in cultures and institutions had significant impact on trust (Arino et al., 2001). According to Arino et al. (2001) trustworthiness in strategic alliances was rooted in the cultural context of the firms within the alliance. This leads to the generation of the first proposition:

P1: Cultural compatibility among firms has positive effect on the level of trust in strategic alliances.

However, building trust within strategic alliance is also affected by strategic intent (the motivation for formation of the alliances). Such a motivation should range from the economic (e.g. for economy of scale, efficiency, risk sharing) to the more complex (e.g. learning new technologies, seeking political advantage). Parties involved in a strategic alliance should share the same motivation for becoming long-term partners. It should be a win-win situation for all firms and, to the extent that organizations involved in the alliance have closer motivation and objectives, the level of trust between them increases. Arino et al. (2001) argued that strategic changes in each party's goals could affect the level of trust among them. They indicated that changes in strategic objectives posed a great threat to the level of trust among partners. Accordingly, it is proposed that

P2: The closer the strategic intent (direction) of the firms, the greater the degree of trust among firms in strategic alliances.
It has been asserted that without cooperative learning the success of strategic alliances will be limited in the long term (Morrison and Mezentseff, 1997). The role of leaders within the alliance is to provide an environment that people can easily share their knowledge and information with each other. Successful alliance governance develops trust. According to Gulati et al. (1994), ensuring an open and free flow of information between the partners in the alliance is important element in managing the process dynamics of alliances. Management style and leadership is a key element in the success of strategic alliance (Browning et al., 1995). Previous studies indicate that network governance fosters trust and facilities communication (Paulraj et al., 2007). In fact, in is believed that effective governance mechanism reduces transactions costs, which means higher level of trust. Effective governance can generate relational rents by either (1) lowering transactions costs or (2) providing incentives for value creation initiatives (Dyer and Singh, 1998). Therefore,

P3: Effective alliance governancope (leadership) has a positive effect on building trust in strategic alliances.

Formation of trust helps in knowledge sharing among partners in the alliance. Koka and Prescott (2002) indicated that firms' commitment dedicated to building relationships enhanced access to information, since partners shared more information with each other. Gulati (1998) argued that trust not only enabled greater exchange of information, it also promoted ease of interaction and a flexible orientation on the part of each partner. Partners share information with confidence because of the development of trust (Koka and Prescott, 2002). Empirical research also supports that development of trust between alliance partners affects knowledge sharing between them ([Uzzi, 1996] and [Uzzi, 1997]). From the social capital theory, trust allows for greater benefits of knowledge sharing and joint learning (Nahapiet and Ghoshal, 1998; Inkpen, 2001; Ireland and Webb, 2007). Therefore, it is proposed that

P4: Trust positively affects cooperative learning in strategic alliances.

Learning within a mutual collaboration and within strategic alliances requires trust and honesty (Crossan and Inkpen, 1995). Learning emerges through the communication and information sharing in strategic alliances (Browning et al., 1995), which in turn enhances the level of trust among partners. Arino et al. (2001) stated that the interactions between partners led to constantly evolving relationships where the tests of loyalty and fidelity occurred periodically. Levinthal and March (1993) asserted that strong ties with partners in alliances resulted in exploitative learning-learning activities that include refinement, choice, production, efficiency, selection, implementation, and execution (March, 1991; Schildt et al., 2005). Through relational processes partners learn about each other's competency and develop confidence in one another (Muthusamy and White, 2005). Thus, 
P5 : Cooperative learning enhances trust within the strategic alliances.

Firms in the alliance attempt to systematically diffuse knowledge throughout their organization (Hamel et al., 1989). Crossan and Inkpen (1995) demonstrated that learning was directly linked to the ability of the firms to develop a sustainable competitive advantage. In that regard, learning positively affects the performance of firms. Garvin (1993) justified that continuous improvement requires a commitment to learning. Knowledge acquired within an alliance is valuable after it has been diffused through the organization (Hamel et al., 1989). Accordingly, learning should enhance continuous improvement of processes in firms within the alliance.

$\mathrm{P}_{\mathrm{b}}$ : Cooperative learning positively affects process improvement in strategic alliances.

Continuous improvement is defined as the ability of the firm to continuously improve its processes (Dean and Bowen, 1994). Within the MBNQA model, research shows that process improvements affect firm performance (Wilson and Collier, 2000). Therefore,

$\mathrm{P}_{\mathrm{a}}$ : Process improvement positively affects performance in strategic alliances.

It is believed that higher level of performance and productivity will be achieved through emphasis on process improvement (Kaynak, 2003). We expect that continuous improvement of the processes will result in higher customer satisfaction as the quality of products and/or services improves. Within strategic alliances, where firms are viewed as customers to each other it is expected that process improvement within the alliance will lead to higher satisfaction for firms within the alliance. Accordingly it is proposed that

$\mathrm{P}_{\mathrm{b}}$ : Process improvement positively affects alliance satisfaction in strategic alliances.

While there is strong evidence on the initial level of trust among partners in any strategic alliance and network of firms, empirical evidence shows that high level of initial trust does not necessarily lead to alliance success (Arnulf et al., 2005). Companies need to focus on their core competency - the activities that can be leveraged in a pursuit of alliance success (Prahalad and Hamel, 1989). If the role of the firm in an alliance does not correspond to their potential roles and responsibilities (i.e. core competency), they cannot perform well as they are expected by the partners. Well-defined roles for firms in an alliance will improve the level of trust within the alliance. If a firm is not focusing on its core competency within the alliance, it cannot perform well, which leads to lack of trust to the firm. Firms that establish high level of initial trust may not maintain that level of trust due to mismatch between their role and their core competency within the alliance (Arnulf et al., 2005). Accordingly, we propose that

P7: Role clarity of the firms within the alliance has a mediating effect on the level of trust and cooperative learning among firms in the alliance.
Understanding how alliance-specific and firm-level-specific factors impact the success of the alliance is an important question yet not fully investigated (Rothaermel and Deeds, 2006). Gulati et al. (2000) argued that both exogenous and endogenous variables could explain how strategic alliances and networks evolved over time. In that regard, the proposed model for QM within strategic alliances addresses this issue. The environmental variables (culture, strategic intent) serve as exogenous variables in the model. Madhavan et al. (1998) indicated that environmental variables should be regarded as exogenous variables. Therefore, the model covers this issue as well.

\section{Discussion}

It has been argued that the processes by which trust forms initially are not the same as those by which it forms later on. Schoorman et al. (2007) indicate that the dynamics of formation of trust before entering into an alliance is a calculative type (calculative-based trust). As firms enter into the alliances, they utilize a knowledge-based trust. According to McKnight et al. (1998), firms might have high initial trust but it may not be high later because of the situation. With reference to the proposed model, while firms within an alliance may have an initial high level of trust (due to the institutional factors stemmed from their structure, culture, and strategic intent), they may not maintain that level of trust or lose it. The argument here is that cooperative learning is the key for maintaining or improving trust. In other words, to the extent that firms can develop an effective learning environment they can improve the level of trust. The learning mechanism introduced in this paper can explain why trust can decrease despite the fact that firms had an initially high level of trust.

Both the top management perspective and the network perspective have been included in the framework. It has been indicated that both top managers and network/institutional perspectives were important for understanding patterns in the adoption of innovations among organizations (Young et al., 2001). While the role of the top manager has been recognized as one of the key variables in the model, the network effect has been considered as well. The inclusion of top management's role in the model is consistent with the role of top managers in the MBNQA model, where it addresses the critical role of managers in organization-wide quality improvement (Wilson and Collier, 2000; Lee et al., 2003).

The formation of any network of firms is based on the acknowledgement that a partner possesses the useful knowledge, skills, competencies, and capabilities $(\mathrm{Mu}-$ thusamy and White, 2005). With this in mind, top managers need to assess their partners' ability to make sure the partner can contribute to the alliance. This is called the ability-based trust, the skills, competencies, and characteristics that enable a firm to be a potential partner. From the proposed model, it appears that it is the role of top managers to have a realistic assessment of the potential partner's ability. However, as the firms experience the dynamics of alli- 
ance (i.e. after its formation), the level of trust in a partner increases (or decreases) in two ways: (1) a partner adheres to a set of principles that the other firms find acceptable (integrity-based trust) and (2) a partner will not take excessive advantage of other partners when the opportunity is available (benevolence-based trust). It is suggested that all these factors (ability, integrity, and benevolence) may vary independently of others (Mayer et al., 1995). However, they can represent the level of trust in a partner collectively.

It is believed that effectiveness of QM requires that managers maintain a balance between quality control and quality learning (Sitkin et al., 1994). While within stable contexts a quality control approach seems effective, achieving quality goals in a risky and unpredictable environment requires knowledge, learning, and process innovation. In that regard, our proposed model is consistent with previous literature on QM. First, in the context of highly unpredictable environments such as strategic alliances, it addresses the role of learning in effective management of the alliance. Second, it integrates both perspectives on QM. In terms of learning, it demonstrates the dynamics of learning in alliances. With respect to control, it emphasizes the role of trust as a control mechanism. In strategic alliances trust is viewed as a substitute for costly control and coordination mechanism (Bradach and Eccles, 1989; Bromiley and Cummings, 1995). Accordingly, our proposed model integrates quality control and quality learning so that a sustainable QM can be maintained.

\section{Future research}

We have defined two outcomes for a strategic alliance: performance and customer satisfaction. While performance encompasses the overall performance of the alliance, customer satisfaction is related to each individual firm, to the extent that each firm is satisfied with their alliance experience. Empirical research is needed to determine the applicability of the proposed framework.

From the strategic management perspective, there are other variables that affect the formation of trust and learning within an alliance. Among those the role of power or influence in inter-organizational relationship needs to be mentioned. Depending upon the influence of the partners on each other, power relationships may be symmetric (balanced) or asymmetric (unbalanced) (Muthusamy and White, 2005). A symmetric/balanced power structure happens when partners possess the same capability while an asymmetric/unbalanced situation arises from the influence of one (or more partners) on other partners. In our proposed model, we assumed that a symmetric/balanced situation exists. Future research could investigate the dynamics in the asymmetric/unbalanced relationships.

\section{Conclusion}

Our attempt was to address the concept of quality management in strategic alliances and networks of firms. We utilized a learning perspective on quality management that was consistent with the learning perspective of strategic alliances. In line with previous studies in quality management and learning, we addressed both the control and learning aspects of quality management within strategic alliances. Trust emerged as a control mechanism, while cooperative learning and process improvement were key variables facilitating learning dynamics in the alliances.

The propositions based upon the proposed model provide the basis for testable hypotheses. Appropriately testing the hypotheses should add to our understanding of, the relationships between, and the realm of applicability of both quality management and strategic alliances.

\section{References}

Anderson et al., 1994: J. C. Anderson, M. Rungtusanatham, and R. G. Schroeder, A theory of quality management underlying Deming management method, Academy of Management Review 19 (3) (1994), pp. 472-509.

Argyris and Schön, 1978: C. Argyris and D. A. Schön, Organizational Learning: A Theory of Action Perspective, Addison-Wesley, Reading, MA (1978).

Arino et al., 2001: A. Arino, J. De La Torre, and P. S. Ring, Relational quality: Management trust in corporate alliances, California Management Review 44 (1) (2001), pp. 109-131.

Arnulf et al., 2005: J. K. Arnulf, H. C. Dreyer, and C. E. Grenness, Trust and knowledge creation: How the dynamics of trust and absorptive capacity may affect supply chain management development projects, International Journal of Logistics: Research and Applications 8 (3) (2005), pp. 225-236.

Barney, 1991: J. B. Barney, Firm resources and sustained competitive advantage, Journal of Management 17 (1) (1991), pp. 99-120.

Bradach and Eccles, 1989: J. L. Bradach and R. G. Eccles, Price, authority and trust: From ideal types to plural forms, American Review of Sociology 15 (1989), pp. 97-118.

Bromiley and Cummings, 1995: P. Bromiley and L. L. Cummings, Transaction costs in organizations with trust. In: R. Bies, B. Sheppard and R. Lewicki, Editors, Research on Negotiations vol. 5, JAI Press, Greenwich, CT (1995), pp. 219-247.

Browning et al., 1995: L. D. Browning, J. M. Beyer, and J. C. Shetlerr, Building cooperation in a competitive industry: SEAMTECH and the semiconductor industry, Academy of Management Journal 38 (1) (1995), pp. 113-151.

Cohen and Levinthal, 1990: W. M. Cohen and D. A. Levinthal, Absorptive capacity: A new perceptive on learning and innovation, Administrative Science Quarterly 35 (1) (1990), pp. 128-152.

Christopher, 1998: M. Christopher, Logistics and Supply Chain Management: Strategies for Reducing Costs and Improving Service, Financial Times, London, UK (1998).

Crossan and Inkpen, 1995: M. Crossan and A. Inkpen, The subtle art of learning through alliances, Business Quarterly 60 (2) (1995), pp. 68-78.

Das et al., 2000: A. Das, R. J. Handfield, and S. Ghosh, A contingent perspective of quality management-The impact of international competition on quality, Decision Sciences 31 (3) (2000), pp. 649-690.

Das and Teng, 1998: T. K. Das and B. Teng, Between trust and control: Developing confidence in partner cooperation in alliances, Academy of Management Review 23 (3) (1998), pp. 491-512.

Davis et al., 2000: J. H. Davis, F. D. Schoorman, R. C. Mayer, and H. H. Tan, The trusted general manager and business unit performance: Empirical evidence of a competitive advantage, Strategic Management Journal 21 (5) (2000), pp. 563-576.

Dean and Bowen, 1994: J. W. Dean and D. E. Bowen, Management theory and total quality: Improving research and practice through 
theory development, The Academy of Management Journal 19 (3) (1994), pp. 392-418.

Deming, 1982: W. E. Deming, Quality, Productivity, and Competitive Position, Center for Advanced Engineering Study, Massachusetts Institute of Technology, Cambridge, MA (1982).

Deming, 1986: W. E. Deming, Out of the Crisis, MIT Press, Cambridge, MA (1986).

Deming, 1994: W. E. Deming, The New Economics for Industry, Education, Government (second ed), MIT Press, Cambridge, MA (1994).

DiMaggio and Powell, 1983: P. J. DiMaggio and W. W. Powell, The iron cage revisited: Institutional isomorphism and collective rationality in organizational fields, American Sociological Review 48 (2) (1983), pp. 147-160.

Douglas and Judge, 2001: T. J. Douglas and W. Q. Judge Jr., Total quality management implementation and competitive advantage: The role of structural control and exploration, Academy of Management Journal 44 (1) (2001), pp. 158-169.

Dyer, 1996: J. H. Dyer, Effective interfirm collaboration: How firms minimize transaction cost and maximize transaction value, Strategic Management Journal 18 (7) (1996), pp. 535-556.

Dyer and Singh, 1998: J. H. Dyer and H. Singh, The relational view: Cooperative strategy and sources of interorganizational competitive advantage, Academy of Management Review 23 (4) (1998), pp. 660-679.

Ellram, 1990: L. M. Ellram, The supplier selection decision in strategic partnership, Journal of Purchasing and Material Management 26 (1) (1990), pp. 8-14.

Escrig Tena et al., 2001: A. B. Escrig Tena, J. C. Bou Llusar, and V. Roca Puig, Measuring the relationship between total quality management and sustainable competitive advantage: A resource-based view, Total Quality Management 12 (7\&8) (2001), pp. 932-938.

Evans and Jack, 2003: J. R. Evans and E. P. Jack, Validating key results linkages in the Baldrige performance excellence model, Quality Management Journal 10 (2) (2003), pp. 7-24.

Fine, 1986: C. H. Fine, Quality improvement and learning in productive systems, Management Science 32 (10) (1986), pp. 1301-1315.

Fine and Porteus, 1989: C. H. Fine and E. L. Porteus, Dynamic process improvement, Operations Research 37 (4) (1989), pp. 580-591.

Flynn and Flynn, 2005: B. B. Flynn and E. J. Flynn, Synergies between supply chain management and quality management: Emerging implications, International Journal of Production Research 16 (15) (2005), pp. 3421-3463.

Flynn and Saladin, 2001: B. B. Flynn and B. Saladin, Further evidence on the validity of the theoretical models underlying the Baldrige criteria, Journal of Operations Management 19 (3) (2001), pp. 617-652.

Flynn et al., 1994: B. B. Flynn, R. G. Schroeder, and S. Sakakibara, A framework for quality management research and an associated instrument, Journal of Operations Management 11 (4) (1994), pp. 339-366.

Garvin, 1993: D. Garvin, Building a learning organization, Harvard Business Review 71 (4) (1993), pp. 78-91.

Gulati, 1995: R. Gulati, Does familiarity breed trust? The implications of repeated ties for contractual choice in alliances, Academy of Management Journal 38 (1) (1995), pp. 85-112.

Gulati, 1998: R. Gulati, Alliances and networks, Strategic Management Journal 19 (4) (1998), pp. 293-317.

Gulati et al., 1994: R. Gulati, T. Khanna, and N. Nohria, Unilateral commitments and the importance of process in alliance, Sloan Management Review 35 (3) (1994), pp. 61-69.

Gulati et al., 2000: R. Gulati, N. Nohira, and A. Zaheer, Strategic networks, Strategic Management Journal 21 (3) (2000), pp. 203-215.

Hackman and Wageman, 1995: J. R. Hackman and R. Wageman, Total quality management: Empirical, conceptual and practical implications, Administrative Science Quarterly 40 (2) (1995), pp. 309-342.

Hamel et al., 1989: G. Hamel, Y. L. Doz, and C. K. Prahalad, Collaborate with your competitors - And win, Harvard Business Review 67 (1) (1989), pp. 133-139.
Handfield et al., 1998: R. B. Handfield, S. Ghosh, and S. Fawcett, Quality-driven change and its effects on financial performance, Quality Management Journal 5 (3) (1998), pp. 13-30.

Heide, 1994: J. B. Heide, Interorganizational governance in marketing channels, Journal of Marketing 58 (1) (1994), pp. 71-86.

Hendricks and Singhal, 1996: K. B. Hendricks and V. R. Singhal, Does implementing an effective TQM program actually improve operating performance? Empirical evidence from firms that have won quality awards, Management Science 43 (9) (1996), pp. 1258-1274.

Hendricks and Singhal, 2001a: K. B. Hendricks and V. R. Singhal, Firms characteristics, total quality management, and financial performance, Journal of Operations Management 19 (3) (2001), pp. 269-285.

Hendricks and Singhal, 2001b: K. B. Hendricks and V. R. Singhal, The long-term stock price performance of firm with effective TQM programs, Management Science 47 (3) (2001), pp. 359-368.

Inkpen, 2001: A. C. Inkpen, Strategic alliances. In: M. A. Hitt, R. E. Freeman and J. S. Harrsion, Editors, Handbook of Strategic Management, Blackwell Publishers, Malden, MA (2001), pp. 409-432.

Inkpen, 2005: A. C. Inkpen, Learning through alliances: General Motors and NUMMI, California Management Review 47 (4) (2005), pp. 114-136.

Inkpen and Ross, 2001: A. C. Inkpen and J. Ross, Why do some strategic alliances persist beyond their useful life?, California Management Review 44 (1) (2001), pp. 132-148.

Ireland and Webb, 2007: R. D. Ireland and J. W. Webb, A multi-theoretic perspective on trust and power in strategic supply chain, Journal of Operations Management 25 (2) (2007), pp. 482-497.

Jeffries and Reed, 2000: F. L. Jeffries and R. Reed, Trust and adaptation in relational contracting, Academy of Management Review 25 (4) (2000), pp. 873-882.

Jones and George, 1998: G. R. Jones and J. M. George, The experience and evolution of trust: Implications for cooperation and teamwork, Academy of Management Review 23 (3) (1998), pp. 531-546.

Judge and Zeithaml, 1992: W. Q. Judge and C. P. Zeithaml, Institutional and strategic choice perspectives on board involvement in the strategic decision process, Academy of Management Journal 35 (4) (1992), pp. 766-794.

Kanji, 1990: G. K. Kanji, Total quality management: The second industrial revolution, Total Quality Management 1 (1) (1990), pp. 3-13.

Kaynak, 2003: K. Kaynak, The relationship between total quality management practices and their effects of firm performance, Journal of Operations Management 21 (4) (2003), pp. 405-435.

Koka and Prescott, 2002: B. R. Koka and J. E. Prescott, Strategic alliances as social capital: A multidimensional view, Strategic Management Journal 23 (9) (2002), pp. 795-816.

Kolesar, 1994: P. J. Kolesar, What Deming told the Japanese in 1950, Quality Management Journal 2 (1) (1994), pp. 9-24.

Lee et al., 2003: S. M. Lee, B. H. Rho, and S. G. Lee, Impact of Malcolm Baldrige National Quality Criteria on organizational quality performance, International Journal of Production Research 41 (9) (2003), pp. 2003-2020.

Leonard-Barton, 1992: D. Leonard-Barton, The factory as a learning laboratory, Sloan Management Review 34 (1) (1992), pp. 23-38.

Levinthal and March, 1993: D. A. Levinthal and J. G. March, The myopia of learning, Strategic Management Journal 14 (8) (1993), pp. 95-112.

Li and Rajagopalan, 1998: G. Li and S. Rajagopalan, Process improvement, quality and learning effects, Management Science 44 (11) (1998), pp. 1517-1532.

Linderman et al., 2004: K. Linderman, R. G. Schroeder, S. Zaheer, C. Liedtke, and A. S. Choo, Integrating quality management practices with knowledge creation processes, Journal of Operations Management 22 (6) (2004), pp. 589-607.

Love et al., 2002: P. D. Love, Z. Irani, E. Cheng, and H. Li, A model for supporting inter-organizational relations in the supply chain, Engineering, Construction, and Architectural Management 9 (1) (2002), pp. 2-15. 
Lo and Yeung, 2004: V. H. Y. Lo and A. H. W. Yeung, Practical framework for strategic alliance in Pearl River Delta manufacturing supply chain: A total quality approach, International Journal of Production Economics 87 (3) (2004), pp. 231-240.

Lo et al., 2007: V. H. Y. Lo, A. H. W. Yeung, and A. C. L. Yeung, How supply quality management improves on organization's quality performance: A study of Chinese manufacturing firms, International Journal of Production Research 45 (15) (2007), pp. 2219-2243.

Madhavan et al., 1998: R. Madhavan, B. R. Koka, and J. E. Prescott, How industry events (re)shape interfirm relationships?, Strategic Management Journal 19 (5) (1998), pp. 439-450.

Marcellus and Dada, 1991: R. L. Marcellus and M. Dada, Interactive process quality improvement, Management Science 37 (11) (1991), pp. 1365-1376.

March, 1991: J. March, Exploration and exploitation in organizational learning, Organization Science 2 (1) (1991), pp. 58-70.

McKnight et al., 1998: H. D. McKnight, L. Larry, L. L. Cummings, and N. L. Chervany, Initial trust formation in new organizational relationships, Academy of Management Review 23 (3) (1998), pp. 473-490.

Meyer and Rowan, 1977: J. W. Meyer and B. Rowan, Institutional organizations: Formal structure as myth and ceremony, American Journal of Sociology 83 (2) (1977), pp. 340-363.

Mayer et al., 1995: R. C. Mayer, J. H. Davis, and D. D. Schoorman, An integrative model of organizational trust, Academy of Management Review 20 (3) (1995), pp. 709-734.

Morrison and Mezentseff, 1997: M. Morrison and L. Mezentseff, Learning alliances - A new dimension of strategic alliances, Management Decision 35 (5) (1997), pp. 351-357.

Muthusamy and White, 2005: S. K. Muthusamy and M. A. White, Learning and knowledge transfer in strategic alliances: A social exchange view, Organization Studies 26 (3) (2005), pp. 415-441.

Nahapiet and Ghoshal, 1998: J. Nahapiet and S. Ghoshal, Social capital, intellectual capital and the organizational advantage, Academy of Management Review 23 (2) (1998), pp. 242-266.

Paulraj et al., 2007: A. Paulraj, A. A. Lado, and I. J. Chen, Inter-organizational communication as a relational competency: Antecedents and performance outcomes in collaborative buyer-supplier relationships, Journal of Operations Management 26 (1) (2007), pp. 45-64.

Prahalad and Hamel, 1989: C. K. Prahalad and G. Hamel, The core competency of the corporation, Harvard Business Review 68 (3) (1989), pp. 79-91.

Porter, 1985: M. E. Porter, Competitive Advantage: Creating and suStaining Superior Performance, The Free Press, New York, NY (1985).

Powell, 1995: T. Powell, Total quality management as competitive advantage: A review and empirical study, Strategic Management Journal 16 (1) (1995), pp. 15-37.

Pruett and Thomas, 1996: M. Pruett and H. Thomas, Thinking about quality and its link to strategic management, European Management Journal 14 (1) (1996), pp. 34-46.

Reed et al., 1996: R. Reed, D. J. Lemak, and J. C. Montgomery, Commitment to total quality management: Is there a relationship with firm performance?, Journal of Quality Management 2 (1) (1996), pp. 67-87.

Ring and Van de Ven, 1994: P. S. Ring and A. H. Van de Ven, Developmental process of cooperative interorganizational relationships, Academy of Management Review 19 (1) (1994), pp. 90-118.

Robinson and Malhotra, 2005: C. J. Robinson and M. K. Malhotra, Defining the concept of supply chain quality management and its relevance to academic and industrial practice, International Journal of Production Economics 96 (3) (2005), pp. 315-337.

Rothaermel and Deeds, 2006: F. T. Rothaermel and D. L. Deeds, Alliance type, alliance experience and alliance management capability in high-technology ventures, Journal of Business Venturing 21 (4) (2006), pp. 429-460.

Rumelt, 1984: R. P. Rumelt, Towards a strategic theory of the firm. In: R. B. Lamb, Editor, Competitive Strategic Management, PrenticeHall, Englewood Cliffs, NJ (1984), pp. 556-571.
Sampson, 2005: R. C. Sampson, Experience effects and collaborative results in R\&D alliances, Strategic Management Journal 26 (11) (2005), pp. 1009-1031.

Schildt et al., 2005: H. A. Schildt, M. V. J. Maula, and T. Keil, 2005. Explorative and exploitative learning from external corporate ventures. Entrepreneurship: Theory \& Practice 25 (4), 493-515.

Schoorman et al., 2007: F. D. Schoorman, R. C. Mayer, and J. H. Davis, An integrative model of organizational trust: Past, present, and future, Academy of Management Review 32 (2) (2007), pp. 344-354.

Singh and Mitchell, 2005: K. Singh and W. Mitchell, Growth dynamics: The relationship between interfirm collaboration and business sales in entrant and incumbent alliances, Strategic Management Journal 26 (6) (2005), pp. 497-521.

Sitkin et al., 1994: S. M. Sitkin, K. M. Sutcliffe, and R. G. Schroeder, Distinguishing control from learning in total quality management: A contingency perspective, The Academy of Management Review 19 (3) (1994), pp. 537-564.

Smith et al., 1995: K. G. Smith, S. J. Carroll, and S. J. Ashford, Intraand inter-organizational cooperation: Toward a research agenda, Academy of Management Journal 38 (1) (1995), pp. 7-23.

Sousa and Voss, 2002: R. Sousa and C. A. Voss, Quality management re-visited: A reflective review and agenda for future research, Journal of Operation Management 20 (1) (2002), pp. 91-109.

Stabell and Fjeldstad, 1998: C. B. Stabell and O. D. Fjeldstad, Configuring value for competitive advantage: On chains, shops and networks, Strategic Management Journal 19 (5) (1998), pp. 413-437.

Uzzi, 1996: B. Uzzi, The sources and consequences of embeddedness for the economic performance of organizations: The network effect, American Sociological Review 61 (4) (1996), pp. 674-698.

Uzzi, 1997: B. Uzzi, Social structure and competition in interfirm networks: A paradox of embeddedness, Administrative Science Quarterly 42 (1) (1997), pp. 35-67.

Westphal et al., 1997: J. D. Westphal, R. Gulati, and S. M. Shortell, Customization or conformity? An institutional perspective on the content and consequences of TQM adoption, Administrative Science Quarterly 42 (2) (1997), pp. 366-394.

White and Lui, 2005: S. White and S. S. Lui, Distinguishing cost of cooperation and control in alliances, Strategic Management Journal 26 (10) (2005), pp. 913-932.

Wicks, 2001: A. C. Wicks, The value dynamics of total quality management: Ethics and the foundations of TQM, Business Ethics Quarterly 11 (3) (2001), pp. 501-536.

Williams, 2007: M. Williams, Building genuine trust through interpersonal emotion management: A threat regulation model of trust and collaboration across boundaries, Academy of Management Review 32 (2) (2007), pp. 595-621.

Williamson, 1979: O. E. Williamson, Transaction-cost economics: The governance of contractual relations, Journal of Law and Economics 22 (2) (1979), pp. 233-261.

Wilson and Collier, 2000: D. D. Wilson and D. A. Collier, An empirical investigation of the Malcolm Baldrige National Quality Award casual model, Decision Sciences 31 (2) (2000), pp. 361-383.

Wong, 2001: A. Wong, Leadership for effective supply chain partnership, Total Quality Management 21 (7\&8) (2001), pp. 913-919.

Yeung et al., 2006: A. C. L. Yeung, T. C. Edwin Cheng, and K. Lai, An operational and institutional perspective on total quality management, Production and Operations Management 15 (1) (2006), pp. 156-170.

Young et al., 2001: G. J. Young, M. P. Charns, and S. M. Shortell, Top manager and network effect on the adoption of innovative management practices: A study of TQM in a public hospital system, Strategic Management Journal 22 (10) (2001), pp. 935-951.

Zollo et al., 2002: M. Zollo, J. Reuer, and H. Singh, Interorganizational routines and performance in strategic alliances, Organization Science 13 (6) (2002), pp. 701-713. 